\title{
Profil Hematologi Tikus (Rattus norvegicus Berkenhout, 1769) Galur Wistar Jantan dan Betina Umur 4, 6, dan 8 Minggu
}

\author{
LAKSMINDRA FITRIA $^{1}$, MULYATI SARTO ${ }^{1}$ \\ ${ }^{1}$ Laboratorium Fisiologi Hewan, Fakultas Biologi, Universitas Gadjah Mada \\ Jl. Teknika Selatan Sekip Utara Sleman Yogyakarta 55281 \\ email: laksmindraf@ugm.ac.id
}

\begin{abstract}
Animal model is very important in biomedical research. Prior to apply in human or other primates, experiments using lower animals model such as rodents must be conducted (preclicical studies). Wistar rats (Rattus norvegicus Berkenhout, 1769) are used extensively for in vivo studies, particularly in physiology. However, their normal hematology profile for baseline or control has not been yet available locally. Many researchers adopt data from general references such as clinical or laboratory manual books, journals, textbooks, or other resources, which definitely affect the validity of their results. This study was carried out to provide normal hematology profile of male and female Wistar rats bred in animal house of Laboratorium Penelitian dan Pengujian Terpadu Universitas Gadjah Mada (LPPT-UGM). Subjects were four-, six-, and eight-week-old rats, representative for juvenile/ immature, preadult, and adult/mature, respectively. Procedures following routine standard method in hematology: blood withdrawal from sinus retro-orbitalis of ketamine-anesthetized animals and analysis using Hematology Analyzer. Variables were number of erythrocytes, hemoglobin, hematocrit, number of leukocytes and differential count, number of thrombocytes, and body mass. Results indicated that hematology profile and body mass of rats from different sex and different age were varied. It is fundamental to have local baseline data, which directly come from animal house. Adoption from other references should be avoid due to generality or unspecified animal, lack of information on methods, and some works have already outdated. Different sex, age, environmental factors, and method affect physiological condition in animals, result in different hematology profile.
\end{abstract}

Keywords: erythrocytes, hematology, leukocytes, thrombocytes, Wistar rats

\section{PENDAHULUAN}

Hewan model (hewan coba) sangat diperlukan dalam penelitian in vivo di bidang biomedik (Hewitt et al., 1989; Iheidioha et al., 2012), terutama untuk kajian imunologi, onkologi, fisiologi, patologi, toksikologi, farmakologi, dan neurosains (Johnson, 2012; Iheidioha et al., 2012).

Sebelum diaplikasikan kepada manusia atau primata lainnya, serangkaian percobaan menggunakan hewan model harus dilakukan terlebih dahulu (disebut penelitian praklinik). Anggota Rodentia seperti tikus (Rattus norvegicus) dan mencit (Mus musculus) sering dijadikan hewan model karena memiliki sistem faal yang mirip dengan manusia (Smith and Mangkoewidjojo, 1988; Johnson, 2012).

Tikus Wistar adalah salah satu hewan coba yang paling banyak digunakan sebagai model dalam penelitian biomedik (Johnson,
2012). Tikus Wistar (albino) dikembangkan pertama kali di Wistar Institute (Philadelphia, PA) pada tahun 1906 dengan nama katalog WISTARAT $^{\circledR} \quad$ (Clause BT, 1998; Wistar $^{2}$ Institute, 2014). Galur ini terus dibiakkan hingga kini karena ideal sebagai hewan model untuk berbagai tujuan penelitian (River, 1998).

Darah merupakan komponen yang sangat penting karena berfungsi untuk mengedarkan substansi yang masuk ke dalam tubuh maupun yang dihasilkan tubuh dari proses-proses metabolisme. Oleh karena itu darah menjadi salah satu parameter pokok dalam penelitian praklinik/biomedik. Hematologi adalah ilmu yang mempelajari cara penilaian darah. Nilai hematologi (profil darah) berguna untuk menilai kondisi kesehatan dan sebagai acuan nilai awal (baseline) atau kontrol dalam suatu penelitian. Adanya gangguan metabolisme, penyakit, kerusakan struktur dan/atau fungsi 
organ, pengaruh agen/obat, dan stres dapat diketahui dari perubahan profil darah (Iheidioha et al., 2012).

Profil darah normal untuk tikus Wistar belum banyak tersedia secara lokal. Masih banyak peneliti yang mengacu nilai hematologi normal dari referensi seperti bukubuku, jurnal, dan sumber-sumber lain yang bersifat umum, tidak spesifik untuk tikus Wistar. Pada Rodentia, variasi nilai fisiologis antar galur dalam satu species sangat tinggi, termasuk nilai hematologi. Kisaran nilai hematologi normal bervariasi pada individu jantan dan betina, serta perbedaan umur (Jain, 1986 in Smith et al., 1994; River, 1998). Di samping itu, nilai hematologi juga dipengaruhi oleh kondisi geografis, seperti lokasi, iklim, suhu, kelembapan, ketinggian, dan pencahayaan (Iheidioha et al., 2012), sehingga nilai hematologi bersifat spesifik untuk suatu tempat, tidak dapat digeneralisir.

Penelitian ini bertujuan untuk menyediakan data hematologi normal tikus Wistar berdasarkan jenis kelamin dan umur.

\section{METODE}

Semua hewan uji dalam penelitian ini merupakan hasil pengembangbiakan di Laboratorium Penelitian dan Pengujian Terpadu Universitas Gadjah Mada (LPPTUGM Unit IV) sebagai penyedia hewan coba (animal house) yang melayani kebutuhan penelitian di seluruh Indonesia.

Pemeliharaan telah diupayakan memenuhi standar, meliputi: status kesehatan dan kualitas hewan, pengandangan, pemberian pakan dan minum, kebersihan, pemantauan faktor-faktor lingkungan seperti temperatur, kelembapan, pencahayaan, dan kualitas udara, sistem pengembangbiakan yang tercatat, serta teknisi yang berpengalaman (Carlsson, 2008).

Profil hematologi telah ditentukan pada hewan umur 3-12 minggu (lepas sapih sampai dengan dewasa) namun hasil yang ditampilkan adalah untuk umur 4, 6, dan 8 minggu saja. Menurut Fitria dkk. (2009), tikus umur 4, 6, dan 8 minggu adalah yang paling sering digunakan dalam penelitian fisiologis yang dikaitkan dengan fungsi reproduktif. Masingmasing kelompok umur terdiri atas lima ulangan yang diambil secara acak.

Tikus dianestesi secara intramuskular menggunakan ketamin dosis $50 \mathrm{mg} / \mathrm{kg} \mathrm{bb}$, kemudian ditimbang dan dicatat massa tubuh/ berat badannya menggunakan neraca digital Ohauss $^{\circledR}$, dan dinyatakan dalam "gram".

Darah diambil dari sinus retro-orbitalis menggunakan kapilar hematokrit, ditampung ke dalam microtube yang telah ditambahkan bubuk EDTA. Penentuan profil hematologi menggunakan Hematology Analyzer Sysmax KX-2 $1^{\circledR}$. Hasil yang diperoleh adalah: (1) Profil eritrosit: jumlah eritrosit, kadar hemoglobin, dan persentase hematokrit. Melalui alat ini diperoleh juga nilai $\mathrm{MCV}$, $\mathrm{MCH}$, dan MCHC namun hasilnya tidak ditampilkan di sini; (2) Profil leukosit: jumlah total leukosit, jumlah neutrofil, jumlah limfosit, dan mixed (gabungan jumlah monosit, eosinofil, dan basofil); (3) Profil trombosit: jumlah trombosit.

Data yang diperoleh ditabulasi dan ditampilkan sebagai "rerata \pm sd".

\section{HASIL}

Profil hematologi dan berat badan tikus Wistar jantan dan betina disajikan pada Tabel 1 dan Tabel 2 berikut ini.

Tabel 1. Profil hematologi dan berat badan tikus Wistar jantan umur 4, 6, dan 8 minggu yang dikembangbiakkan di LPPT-UGM Unit IV

\begin{tabular}{cccc}
\hline & \multicolumn{3}{c}{ Umur (minggu) } \\
\cline { 2 - 4 } Variabel & 4 & 6 & 8 \\
\hline Eritrosit & 4,87 & 6,22 & 5,50 \\
$\left(\times 10^{6} / \mu \mathrm{L}\right)$ & $\pm 0,81$ & $\pm 1,93$ & $\pm 0,32$ \\
\hline Hemoglobin & 10,09 & 14,67 & 10,63 \\
$(\mathrm{~g} / \mathrm{dL})$ & $\pm 0,34$ & $\pm 3,52$ & $\pm 0,26$
\end{tabular}




\begin{tabular}{cccc}
\hline $\begin{array}{c}\text { Hematokrit } \\
(\%)\end{array}$ & 43,89 & 48,42 & 52,17 \\
$\pm 1,42$ & $\pm 5,57$ & $\pm 5,14$ \\
\hline Leukosit & 8,05 & 7,16 & 8,08 \\
$\left(\times 10^{3} / \mu \mathrm{L}\right)$ & $\pm 2,27$ & $\pm 2,51$ & $\pm 1,08$ \\
\hline Neutrofil & 2,93 & 2,43 & 2,24 \\
$\left(\times 10^{3} / \mu \mathrm{L}\right)$ & $\pm 0,14$ & $\pm 0,23$ & $\pm 0,08$ \\
\hline Limfosit & 5,03 & 4,60 & 5,56 \\
$\left(\times 10^{3} / \mu \mathrm{L}\right)$ & $\pm 0,14$ & $\pm 0,14$ & $\pm 0,05$ \\
\hline Mixed & 0,091 & 0,13 & 0,29 \\
$\left(\times 10^{3} / \mu \mathrm{L}\right)$ & $\pm 0,14$ & $\pm 0,14$ & $\pm 0,06$ \\
\hline Trombosit & 2,28 & 2,01 & 1,47 \\
$\left(\times 10^{5} / \mu \mathrm{L}\right)$ & $\pm 0,49$ & $\pm 0,38$ & $\pm 0,41$ \\
\hline Berat badan & 62,36 & 163,50 & 196,78 \\
$(\mathrm{~g})$ & $\pm 3,82$ & $\pm 13,09$ & $\pm 21,63$ \\
\hline
\end{tabular}

Tabel 2. Profil hematologi dan berat badan tikus Wistar betina umur 4, 6, dan 8 minggu yang dikembangbiakkan di LPPT-UGM Unit IV

Umur (minggu)

\begin{tabular}{|c|c|c|c|}
\hline Variabel & 4 & 6 & 8 \\
\hline $\begin{array}{c}\text { Eritrosit } \\
\left(\times 10^{6} / \mu \mathrm{L}\right)\end{array}$ & $\begin{array}{c}5,16 \\
\pm 0,80\end{array}$ & $\begin{array}{c}6,67 \\
\pm 0,18\end{array}$ & $\begin{array}{c}6,92 \\
\pm 0,38\end{array}$ \\
\hline $\begin{array}{l}\text { Hemoglobin } \\
(\mathrm{g} / \mathrm{dL})\end{array}$ & $\begin{array}{l}11,12 \\
\pm 1,75\end{array}$ & $\begin{array}{l}12,52 \\
\pm 0,95\end{array}$ & $\begin{array}{l}13,44 \\
\pm 0,55\end{array}$ \\
\hline $\begin{array}{c}\text { Hematokrit } \\
(\%)\end{array}$ & $\begin{array}{l}31,80 \\
\pm 4,59\end{array}$ & $\begin{array}{l}36,84^{b} \\
\pm 2,29\end{array}$ & $\begin{array}{l}38,06 \\
\pm 1,61\end{array}$ \\
\hline $\begin{array}{l}\text { Leukosit } \\
\left(\times 10^{3} / \mu \mathrm{L}\right)\end{array}$ & $\begin{array}{c}6,58 \\
\pm 1,16\end{array}$ & $\begin{array}{c}4,90 \\
\pm 0,76\end{array}$ & $\begin{array}{c}5,36 \\
\pm 1,21\end{array}$ \\
\hline $\begin{array}{l}\text { Neutrofil } \\
\left(\times 10^{3} / \mu \mathrm{L}\right)\end{array}$ & $\begin{array}{c}1,34 \\
\pm 0,46\end{array}$ & $\begin{array}{c}1,06 \\
\pm 0,26\end{array}$ & $\begin{array}{c}1,18 \\
\pm 0,28\end{array}$ \\
\hline $\begin{array}{l}\text { Limfosit } \\
\left(\times 10^{3} / \mu \mathrm{L}\right)\end{array}$ & $\begin{array}{c}5,24 \\
\pm 1,36\end{array}$ & $\begin{array}{c}3,84 \\
\pm 0,74\end{array}$ & $\begin{array}{c}4,12 \\
\pm 1,24\end{array}$ \\
\hline $\begin{array}{c}\text { Mixed } \\
\left(\times 10^{3} / \mu \mathrm{L}\right)\end{array}$ & $\begin{array}{c}0,00 \\
\pm 0,00\end{array}$ & $\begin{array}{c}0,00 \\
\pm 0,00\end{array}$ & $\begin{array}{c}0,06 \\
\pm 0,13\end{array}$ \\
\hline $\begin{array}{l}\text { Trombosit } \\
\left(\times 10^{5} / \mu \mathrm{L}\right)\end{array}$ & $\begin{array}{c}7,11 \\
\pm 2,20\end{array}$ & $\begin{array}{c}6,79 \\
\pm 3,20\end{array}$ & $\begin{array}{c}8,39 \\
\pm 1,18\end{array}$ \\
\hline $\begin{array}{l}\text { Berat badan } \\
\text { (g) }\end{array}$ & $\begin{array}{l}59,90 \\
\pm 2,30\end{array}$ & $\begin{array}{c}132,28 \\
\pm 5,86\end{array}$ & $\begin{array}{c}151,60 \\
\pm 8,54\end{array}$ \\
\hline
\end{tabular}


Jumlah eritrosit hewan jantan lebih rendah daripada betina. Jumlah eritrosit pada jantan fluktuatif dengan nilai tertinggi saat umur 6 minggu, sedangkan pada betina jumlah eritrosit meningkat seiring pertambahan umur.

Kadar hemoglobin hewan jantan lebih rendah daripada betina. Kadar hemoglobin pada jantan fluktuatif dengan nilai tertinggi saat umur 6 minggu (lebih tinggi daripada betina), sedangkan pada betina kadar hemoglobin meningkat seiring pertambahan umur.

Nilai hematokrit hewan jantan lebih tinggi daripada betina. Nilai hematokrit pada jantan dan betina meningkat seiring pertambahan umur.

Jumlah leukosit hewan jantan lebih tinggi daripada betina. Jumlah leukosit pada jantan dan betina fluktuatif, nilai terendah saat umur 6 minggu.

Jumlah neutrofil hewan jantan lebih tinggi daripada betina. Jumlah neutrofil pada jantan menurun seiring pertambahan umur, sedangkan pada betina fluktuatif dengan nilai tertinggi saat umur 4 minggu.

Jumlah limfosit hewan jantan lebih tinggi daripada betina kecuali saat umur 4 minggu. Jumlah limfosit pada jantan dan betina fluktuatif dengan nilai terendah saat umur 6 minggu.

Jumlah monosit, eosinofil dan basofil (mixed) hewan jantan lebih tinggi daripada betina. Jumlah mixed pada jantan dan betina meningkat seiring pertambahan umur.

Jumlah trombosit hewan jantan lebih rendah daripada betina. Jumlah trombosit pada jantan menurun seiring pertambahan umur, sedangkan pada betina fluktuatif dengan nilai tertinggi saat umur 8 minggu.

Massa tubuh atau berat badan hewan jantan lebih tinggi daripada betina. Massa tubuh pada jantan dan betina bertambah seiring dengan pertambahan umur.

\section{PEMBAHASAN}

Profil normal merupakan sekumpulan nilai-nilai fisiologis (salah satunya adalah profil hematologi) yang diperoleh dari suatu populasi hewan sehat (sample). Populasi dalam konteks ini mengacu pada tempat asal hewan coba diperoleh (Iheidioha et al., 2012). Dalam kenyataannya, masih banyak peneliti yang mengacu profil hematologi normal berdasarkan referensi umum dan bukan dari penyedia hewan coba setempat (lokal). Literatur yang digunakan kadang berasal dari luar negeri, tidak spesifik untuk tikus Wistar, tidak dibedakan jenis kelamin dan umur, serta umur data telah usang.

Benjamin (1964) dan Mitruka and Rawnsley (1981) menyajikan profil hematologi normal untuk tikus secara umum, tidak ada spesifikasi galur, jenis kelamin, dan umur. Selain itu umur data telah cukup tua. Sementara itu Moore (1986) menyajikan profil hematologi normal untuk beberapa galur tikus yang sering digunakan dalam penelitian, yaitu Wistar, Sprague-Dawley, Long-Evans, dan F344, telah dibedakan berdasarkan jenis kelamin dan umur, namun umur data juga sudah cukup lama. Ketiga acuan ini menggunakan tikus yang dikembangbiakkan di luar negeri dengan kondisi lingkungan yang tidak sama dengan di Indonesia.

Smith dan Mangkoewidjojo mempublikasikan nilai hematologi normal untuk tikus yang dikembangbiakkan di negara tropis seperti Indonesia, namun juga masih secara umum, tidak spesifik untuk galur Wistar, dan tidak dirinci berdasarkan jenis kelamin dan umur. Di samping itu tidak ada informasi sumber hewan dan tempat pemeliharaan serta umur data yang juga sudah cukup lama.

Charles River Laboratories mempublikasikan data hematologi normal khusus untuk tikus Wistar yang dikembangbiakkan sendiri (River, 1998). Data telah dikelompokkan berdasarkan jenis kelamin dan umur, lebih lengkap, dan lebih baru namun hewan dikembangbiakkan di Amerika Serikat.

Berdasarkan latar belakang tersebut, maka penelitian ini dilakukan untuk menentukan profil hematologi normal tikus Wistar yang dikembangbiakkan di Indonesia dan telah dikelompokkan berdasarkan jenis kelamin dan umur.

Darah merupakan komponen penting dalam penilaian kondisi fisiologis tubuh. Profil 
darah dapat dibedakan menjadi dua, yaitu: profil hematologi atau hitung lengkap (complete blood count, CBC) dan profil kimia darah (blood clinical chemistry). Profil hematologi mengevaluasi komponen selular, sedangkan profil kimia darah mengevaluasi komponen dalam cairan darah (Mitruka and Rawnsley (1981); River, 1998).

Eritrosit berkaitan dengan fungsi penyediaan oksigen untuk kebutuhan energi dalam rangka metabolisme. Selain itu eritrosit juga berkaitan dengan aktivitas dan stres. Tikus yang dipuasakan selama 17-20 jam akan mengalami peningkatan jumlah eritrosit, hemoglobin, dan hematokrit, sebaliknya terjadi penurunan jumlah leukosit (Kast and Nishikawa, 1981 in Smith et al., 1994). Oleh karena itu hendaknya tidak mempuasakan tikus (juga mencit) overnight. Bila dalam penelitian membutuhkan perlakuan puasa, maka tikus dan mencit cukup dipuasakan selama 6-8 jam saja (Carlson, 2008).

Leukosit berhubungan erat dengan sistem pertahanan tubuh. Neutrofil bertanggung jawab terhadap respon imun bawaan, sedangkan limfosit memegang peranan penting dalan respon imun adaptif. Monosit, eosinofil, dan basofil dalam kondisi normal jumlahnya sangat sedikit, akan meningkat oleh kondisi patologis. Trombosit merupakan komponen utama dalam koagulasi darah dalam rangka hemostasis.

Alat yang digunakan dalam penelitian ini mengakumulasi jumlah monosit, eosinofil, dan basofil sebagai mixed. Dalam penelitian, apabila pada kelompok perlakuan memiliki nilai mixed yang besarnya melebihi kisaran nilai normal (baseline atau kontrol), maka harus dilakukan penghitungan secara manual untuk mendapatkan nilai masing-masing leukosit tadi sehingga dapat dijelaskan leukosit manakah yang merespon terhadap perlakuan yang diberikan.

Massa tubuh hewan jantan yang lebih tinggi dibandingkan betina merupakan ekspresi androgen (testosteron) yang berperan dalam mengendalikan pertumbuhan, dimulai pada masa pubertas dengan target kulit, otot, tulang, serta metabolisme air dan garam (Kaltenback and Dunn, 1980). Testosteron juga memiliki efek stimulasi terhadap eritropoiesis yang berkorelasi dengan umur, yaitu melalui peningkatan kadar eritropoietin dan bekerja langsung pada sumsum tulang (Coviello et al., 2008).

Kisaran nilai hematologi normal bervariasi pada individu jantan dan betina, serta perbedaan umur. Pada umumnya eritrosit, hemoglobin, hematokrit, leukosit, dan trombosit lebih tinggi pada hewan jantan dibandingkan betina. Jumlah eritrosit meningkat seiring pertambahan umur, demikian juga kadar hemoglobin. Sebaliknya jumlah leukosit total, neutrofil, limfosit, dan trombosit menurun seiring pertambahan umur (Smith et al., 1994). Dalam penelitian ini, sebagian variabel sesuai dengan Smith et al. (1994), namun sebagian lagi bertolak belakang, seperti jumlah eritrosit, hemoglobin, dan trombosit pada hewan jantan yang lebih rendah dibandingkan betina. Menurut Iheidioha et al. (2012), profil hematologi bervariasi tergantung dari kondisi geografis dan faktor lingkungan setempat. Hasil pengukuran profil darah tikus Wistar di negara tropis pasti berbeda dari yang dilakukan di negara empat musim.

Berdasarkan Tabel 1 dan Tabel 2 dapat dilihat bahwa terdapat perbedaan nilai hematologi antara tikus Wistar jantan dan betina. Nilai ini mengalami peningkatan, penurunan, dan bahkan berfluktuasi pada kelompok umur yang berbeda. Perubahan nilai ini dipengaruhi oleh kebutuhan yang berbeda pada kelompok umur yang berbeda, berkaitan dengan fungsi pertumbuhan dan perkembangan/reproduktif.

Menurut Fitria dkk. (2009), tikus umur 4, 6 , dan 8 minggu adalah yang paling sering digunakan dalam penelitian fisiologis yang dikaitkan dengan fungsi reproduktif. Hal ini didasarkan pada tingkat perkembangan reproduksi, yaitu: 4 minggu untuk stadium muda (juvenile, immature), 6 minggu untuk stadium pradewasa (preadult), dan 8 minggu untuk stadium dewasa awal (adult, mature).

Di samping faktor internal seperti jenis kelamin, umur, dan kondisi patologis, beberapa faktor eksternal dan teknis juga mempengaruhi hasil penilaian, seperti: faktor 
lingkungan, pakan, teknik pemeliharaan, cara sampling darah, dan metode penghitungan, apakah manual atau menggunakan alat/mesin (Smith et al., 1994).

Oleh karena itu nilai normal tidak dapat ditentukan begitu saja berdasarkan referensi secara umum. Nilai normal yang valid ditentukan secara lokal, yaitu berasal dari laboratorium atau animal house sebagai tempat penyedia, pemelihara, dan pengembangbiakan hewan coba yang akan digunakan dalam penelitian.

\section{KESIMPULAN}

Tikus Wistar jantan dan betina pada kelompok umur yang berbeda memiliki profil hematologi dan massa tubuh yang berbeda pula. Hasil dalam penelitian ini untuk hewanhewan yang dikembangbiakkan di LPPTUGM Unit IV. Hewan dari galur yang sama namun dikembangbiakkan di tempat yang berbeda, atau yang telah mengalami aklimasi dapat memiliki profil hematologi dan massa tubuh yang berbeda. Oleh karena itu, nilai normal hendaknya tidak hanya berdasarkan referensi umum saja, namun mengacu ke tempat hewan coba diperoleh (local animal house).

Pembuatan baseline sebagai acuan nilai awal (kontrol) sangat penting untuk penelitian deskriptif maupun eksperimental serta keperluan diagnostik.

\section{UCAPAN TERIMA KASIH}

Terima kasih kepada Laboratorium Penelitian dan Pengujian Terpadu Universitas Gadjah Mada (LPPT-UGM Unit IV) yang telah menyediakan hewan coba dan memfasilitasi penelitian ini. Terima kasih juga kepada para mahasiswa atas kerja samanya dalam penelitian ini: Bekti Budi Utami, Nurul Sekar Winahyu, Dessy Arum Prawestri, Fera Lestyana Devi, Abdullah Langgeng, dan Farah Mawar Firdausi.

\section{DAFTAR PUSTAKA}

Clause BT. 1998. The Wistar Institute Archives: Rats (Not Mice) and History. Mendel Newsletter 7. Hannover: American Philosophical Society Library. http://www.amphilsoc.org/mendel/1998. Diakses 21 November 2014.

Benjamin MM. 1964. Hematological References Values of Rats. In: Outline of Veterinary Clinical Pathology. $2^{\text {nd }}$ ed. Iowa: The Iowa State University Press. pp 58.

Carlsson HE. 2008. The Use of Laboratory Animals in Biomedical Studies. FELASA Category C-Like Course. Bogor: Pusat Studi Satwa Primata Institut Pertanian Bogor (PSSP-IPB).

Coviello AD, Kaplan B, Lakshman KM, Chen T, Singh AB, Bhasin S. 2008. Effects of Graded Doses of Testosterone on Erythropoiesis in Healthy Young and Older Men. J Clin Endocrinol Metab. vol 93(3): 914-919.

Fitria L. 2009. Profil Reproduksi Tikus (Rattus norvegicus Berkenhout, 1769) Stadia Juvenil, Pradewasa, dan Dewasa. Laporan Penelitian Hibah Dosen Muda. Yogyakarta: Lembaga Penelitian dan Pengabdian kepada Masyarakat (LPPMUGM).

Hewitt CD, Innes DJ, Savory J, Willis MR. 1989. Normal Biochemical and Hematological Values in New Zealand White Rabbits. Clinical Chemistry. vol 35(8): 1777-1779.

Ihedioha JI, Ugwuja JI, Noel-Uneke OA, Udeani IJ, Daniel-Igwe G. 2012. Reference Values for the Haematology Profile of Conventional Grade Outbred Albino Mice (Mus musculus) in Nsukka, Eastern Nigeria. ARI. vol 9(2):1601-1612. Johnson M. 2012. Laboratory Mice and Rats. Mater Methods 2:113. http://www.labome.com/method/Laborat ory-Mice-and-Rats.html. Diakses 21 November 2014.

Kaltenback CC and Dunn TG. 1980. Endocrinology of Reproduction. In. Reproduction in Farm Animals. $4^{\text {th }}$ ed. Philadelphia: Lea \& Febiger.

Mitruka BM and Rawnsley HM. 1981. Hematological References Values of Normal Albino Rats. In: Clinical Biochemical and Hematological Reference Values in Normal Experimental 
Animals and Normal Humans. Chicago: Masson Pub. Inc. Year Book Medical Pub. Inc. pp 63-65.

Moore DM. 1986. Hematology of the Rats Rattus norvegicus). In: Feldman BF, Zinkl JG, and Jain NC. (eds). Schalm's Veterinary Hematology. $5^{\text {th }}$ ed. Philadelphia: Lippincott Williams \& Wilkins, a Wolters Kluwer Co.

River C. 1998. Baseline Hematology and Clinical Chemistry Values for Charles River Wistar Rats - (CRL: (WI) BR) as a Function of Sex and Age. Technical Bulletin. Massachusetts: Charles River Laboratories.
Smith CA, Andrews CM, Collard JK, Hall DE, Walker AK. 1994. Rats and Mouse. In: Color Atlas of Comparative Diagnostic \& Experimental Hematology. Barcelona: Wolfe Publishing/Mosby-Year Bok Europe Ltd. pp 9-15.

Smith JB dan Mangkoewidjojo S. 1988. Tikus Laboratorium (Rattus norvegicus). Dalam: Pemeliharaan, Pembiakan, dan Penggunaan Hewan Percobaan di Daerah Tropis. Jakarta: Penerbit Universitas Indonesia (UI-Press). hal 37-57.

Wistar Institute. 2014. Our History. Philadelphia: The Wistar Institute http://www.wistar.org. Diakses 21 November 2014. 